\title{
BIOCHEMICAL AND HISTOPATHOLOGICAL EFFECTS OF COADMINISTRATION OF AMODIAQUINE, ARTESUNATE, AND SELENIUM ON PLASMODIUM BERGHEI INFECTED MICE
}

\author{
ABIODUN HUMPHREY ADEBAYO*, GLORIA NWABUGWU OKENZE, OMOLARA FAITH YAKUBU, \\ MOBOLAJI EMMANUEL ABIKOYE
}

Department of Biochemistry, College of Science and Technology, Covenant University, PMB 1023, Canaan land, Ota, Ogun State, Nigeria. Email: abiodun.adebayo@covenantuniversity.edu.ng

Received: 15 January 2018, Revised and Accepted: 25 February 2018

ABSTRACT

Objective: The effect of coadministering artesunate (ART), amodiaquine (AMO), and selenium were studied on mice induced with Plasmodium berghei.

Methods: The study was conducted using 6 groups of 6 male mice each. Group A constitutes the negative control (unparasitized) while Group B represents the parasite control (parasitized) group. Mice in Groups C, D, E and F, respectively, received $2 \mathrm{mg} / \mathrm{kg}$ bw of ART, $6.12 \mathrm{mg} / \mathrm{kg}$ bw of AMO, combination of AMO and ART, and $0.945 \mathrm{mg} / \mathrm{kg}$ bw of selenium in addition to ART and AMO for 3 days. Thereafter, animals were anesthetized, and the organs were excised. Liver homogenate was prepared and used for analysis of for aspartate aminotransferase (AST), alkaline phosphatase (ALP), alanine aminotransferase (ALT), total protein (TP), reduced glutathione (GSH), catalase (CAT), superoxide dismutase (SOD), and lipid peroxidation (malondialdehyde).

Results: The results showed no significant alteration in AST and ALT, but ALP was significantly (p<0.05) increased in Group D. In addition, a significant drop $(\mathrm{p}<0.05)$ in GSH and SOD activities and significant $(\mathrm{p}<0.05)$ increase in TP was observed in group E. Histopathological studies revealed no degenerative change in the morphology of the hepatocytes of mice in Group F whereas Groups D and E showed mild inflammatory cells.

Conclusion: Conclusively, the combination of ART-AMO therapy with selenium increases the efficacy and reduces potential toxicity of combined antimalarial drugs.

Keywords: Artesunate, Amodiaquine, Selenium, Plasmodium berghei, Antioxidant, Biochemical, Histopathology.

(C) 2018 The Authors. Published by Innovare Academic Sciences Pvt Ltd. This is an open access article under the CC BY license (http://creativecommons. org/licenses/by/4. 0/) DOI: http://dx.doi.org/10.22159/ajpcr.2018.v11s3.29963

\section{INTRODUCTION}

Malaria is still the greatest among the dreaded disease affecting most people in Africa, South America, and Southeast Asia [1]. In 2016, malaria caused an estimated 216 million clinical episodes globally leading to 445,000 deaths. Countries in the World Health Organization (WHO) African region accounted for $91 \%$ of all the malaria deaths followed by $6 \%$ from the WHO Southeast Asia region [2]. The disease is known to be conveyed through the bite of a female Anopheles mosquito carrying the parasite [3]. Plasmodium falciparum accounts for the most dreadful form of malaria compared to other species of Plasmodium that affect humans [4]. Artemisininbased combination therapy (ACT) has been declared as the first-hand treatment for malaria by the WHO. Most ACTs are known to act through the generation of free radicals which can damage internal tissue proteins, nucleic acids, and membranes by lipid peroxidation [5-7]. A general and readily available ACT includes artesunate (ART)-amodiaquine (AMO) and artemether-lumefantrine and (AQ+AS) [8]. At present, ART and AMO combination is available as separate tablets in packs of $153 \mathrm{mg}$ base of AMO and $50 \mathrm{mg}$ of ART. However, the drugs neglected diseases initiative recently developed the coformulated tablets. The endorsed dosage is $10 \mathrm{mg}$ base/ $\mathrm{kg}$ AMO together with $4 \mathrm{mg} / \mathrm{kg}$ bw ART daily for 3 days [9]. The combo has demonstrated efficiency especially in areas with above $80 \%$ cure rate of AMO monotherapy [10]. Selenium is a vital nutrient occupying a position on the periodic table under group VIA [11]. A host of mammals, birds, bacteria, algae, and fishes needs selenium as a vital micronutrient [12]. It is a crucial and significant component of most metabolic processes such as antioxidant defense systems and immune function [13].

The use of antioxidant supplement as part of the treatment regimen of malaria poses a potential strategy against the disease. Therefore, the objective of this study is to evaluate the probable effect of coadministering ART, AMO, and selenium on malaria parasite-induced mice models.

\section{METHODS}

Reagents and drugs

All reagents used in the study were obtained from Randox Laboratories (Crumlin, UK) unless otherwise stated. ART, AMO, and selenium were obtained from Josrite Pharmaceuticals Ota, Nigeria.

\section{Experimental animals}

Male albino Wistar mice (36) having a weight range between 11 and $32 \mathrm{~g}$ were sourced from the University of Agriculture, Abeokuta, Nigeria. The animals were housed in the animal house of Biological Science Department Covenant University Ota, Nigeria, and maintained in $12 \mathrm{~h}$ light: $12 \mathrm{~h}$ dark. They adapted to the environment for 1 week while receiving food and water ad libitum. The handlings of all the experimental animals were done following the approved protocols of the Research Ethics Committee of the Department of Biological Sciences, Covenant University Ota, Nigeria.

\section{Experimental design}

The mice were grouped into 6 groups of 6 male mice each. Each mouse in the parasitized groups received standard intraperitoneal inoculums of $1.0 \times 10^{7}$ Plasmodium berghei parasites. Animals in Groups A and B make up the negative (unparasitized), and parasite control groups were given vehicle (olive oil) only. Mice in Groups C and D were administered $2 \mathrm{mg} / \mathrm{kg}$ bw ART and $6.12 \mathrm{mg} / \mathrm{kg}$ bw AMO, respectively. Animals in Group E were administered a combination of AMO and ART while 
those in Group F received $0.945 \mathrm{mg} / \mathrm{kgbw}$ of selenium in addition to ART and AMO. Treatment lasted for 3 days thereafter the animals were subsequently anesthetized and the organs excised.

\section{Biochemical assays}

Serum alanine aminotransferase (ALT) and aspartate aminotransferase (AST) activities were ascertained by adopting the method of Reitman and Frankel [14] while the serum alkaline phosphatase (ALP) activity was deduced through enzymatic colorimetric method by Wright et al. [15]. Biuret method was followed in determining the protein concentration [16]. Antioxidant parameters were also deduced following established procedures; reduced glutathione (GSH) [17], malondialdehyde (MDA) [18], superoxide dismutase (SOD) [19], and catalase (CAT) [20].

\section{Histological analysis}

Adopting the method of Aliyu et al. [21]; a fraction of the liver tissue was embedded in $10 \%$ formalin after which they were processed for embedding in paraffin [21]. The slide sections were soiled with eosin and hematoxylin stain and analyzed while taking records of photomicrographs using a light microscope.

\section{Statistical analysis}

The Statistical Package for the Social Sciences version 15 was employed to analyze data through one-way analysis of variance and Tukey's test. All data values were expressed as a mean \pm standard error of mean and values were considered statistically significant at $p<0.05$.

\section{RESULTS}

Table 1 shows the effects of the coadministration of selenium, AMO, and ART on the liver parameters in $P$. berghei infected mice. AST and ALT levels were not significantly altered in all groups. However, ALP activity increased significantly $(\mathrm{p}<0.05)$ in mice treated with AMO only. A significant decrease $(\mathrm{p}<0.05)$ was observed in the group treated with selenium and the antimalarial therapy. Moreover, protein concentration significantly increased $(\mathrm{p}<0.05)$ only in the group treated with ART and AMO.

Table 2 shows the influence of coadministration of selenium, AMO, and ART on antioxidant parameters of $P$. berghei infected mice. No significant alteration $(p>0.05)$ in CAT levels in all treated groups was observed whereas a significant drop $(\mathrm{p}<0.05)$ in SOD and GSH activities was discovered in Group E on comparison with the positive control.
Similarly, there was a significant elevation $(p<0.05)$ in the MDA levels in all treated groups on comparison with the control groups.

\section{Histopathological analysis}

Histopathological studies of mice infested with the parasite showed the presence of inflamed cells (Fig. 1). The group administered the ART, AMO, and selenium combination showed no degenerative changes in the morphology of the hepatocytes. Group D and E showed mild inflammation.

\section{DISCUSSION}

This study presents the influence of the coadministering a known ACT (AMO and ART) and selenium on the biochemical and histopathological indices of $P$. berghei infected mice. From our results, exposure of parasitized mice to the antimalarial drugs appears not to significantly affect the liver parameters (ALT and AST). The distortion of the hepatocyte membrane which has been linked to acute liver damage results in the leakage of cytosolic contents of hepatocytes from its membrane [22]. Our observation is in correlation with the findings of Iyawe and Onigbinde [23] as the liver parameters; AST and ALT were not altered significantly with treatment. ALP activity was significantly higher $(\mathrm{p}<0.05)$ in AMO treated mice when compared with the normal control group which may indicate biliary obstruction. However, introducing selenium to the therapy led to a decrease in ALP activity suggesting that selenium may have a protective effect against damage associated with increased ALP. This is in line with the study carried out by Erisir et al. [24].

A notable $(\mathrm{p}<0.05)$ increase in protein concentration was observed in the group administered AMO and ART. High total protein levels in the blood may indicate damage to internal organs such as liver or kidney due to chronic inflammation [25]. This findings correlate with reported studies by Abolaji et al. [26] where they also observed increase in protein levels across all groups administered with the antimalarial drug as compared with the control. Studies have shown that most antimalarial drugs tend to increase lipid peroxidation level while decreasing plasma GSH, Vitamin C, and $\beta$-carotene $[27,28]$. From our results, no significant alteration in CAT level was detected in all treatment groups; however, MDA levels were significantly $(p<0.05)$ increased across all treatment groups as compared with the normal control. The increase in MDA levels could be as a result of

Table 1: Effects of coadministration of selenium, amodiaquine, and artesunate on the liver parameters in Plasmodium berghei infected mice

\begin{tabular}{lllc}
\hline Group & AST (units/L) & ALT (units/L) & ALP (units/L) \\
\hline Normal control (A) & $330.00 \pm 10.00$ & $180.67 \pm 2.67$ & $40.30 \pm 3.21$ \\
Plasmodium berghei only (B) & $343.00 \pm 10.00$ & $189.00 \pm 1.00$ & $17.13 \pm 2.12$ \\
Artesunate only (C) & $368.00 \pm 4.62$ & $192.67 \pm 5.33$ & $27.01 \pm 1.13$ \\
Amodiaquine only (D) & $310.00 \pm 10.00$ & $189.33 \pm 3.53$ & $32.41 \pm 1.46$ \\
ART/AMO (E) & $364.00 \pm 6.00$ & $193.00 \pm 5.00$ & $64.63 \pm 6.63 \mathrm{a}$ \\
ART/AMO/SEL (F) & $333.33 \pm 12.24$ & $191.33 \pm 3.33$ & $36.36 \pm 4.53$ \\
\hline
\end{tabular}

Values represent mean \pm SEM of six replicates, ${ }^{a} \mathrm{p}<0.05$ versus untreated unparasitized, ${ }^{\mathrm{b}} \mathrm{p}<0.05$ versus untreated parasitized. AST: Aspartate transaminase ALT: Alanine transaminase, ALP: Alkaline phosphatase, SEM: Standard error of mean

Table 2: Effects of coadministration of selenium, artesunate, and amodiaquine on antioxidant indices in Plasmodium berghei infected mice

\begin{tabular}{|c|c|c|c|c|}
\hline Group & $\begin{array}{l}\text { GSH } \\
\text { (units/mg protein) }\end{array}$ & $\begin{array}{l}\text { SOD } \\
\text { (units/mg protein) }\end{array}$ & $\begin{array}{l}\text { CAT } \\
\text { (units/mg protein) }\end{array}$ & $\begin{array}{l}\text { MDA } \\
\text { (units/mg protein) }\end{array}$ \\
\hline Normal control (A) & $2.63 \pm 0.77$ & $4.20 \pm 1.43$ & $25.62 \pm 2.44$ & $0.03 \pm 0.003$ \\
\hline Plasmodium berghei only (B) & $0.91 \pm 0.08$ & $2.66 \pm 0.72$ & $26.00 \pm 6.48$ & $0.09 \pm 0.013$ \\
\hline Artesunate only (C) & $1.78 \pm 0.23$ & $4.50 \pm 0.60$ & $31.22 \pm 7.30$ & $0.08 \pm 0.013 a$ \\
\hline Amodiaquine only (D) & $1.38 \pm 0.10$ & $3.98 \pm 0.31$ & $31.01 \pm 0.61$ & $0.09 \pm 0.004 \mathrm{a}$ \\
\hline ART/AMO (E) & $0.83 \pm 0.06 b$ & $1.62 \pm 0.73 b$ & $14.95 \pm 2.67$ & $0.11 \pm 0.014 \mathrm{a}$ \\
\hline ART/AMO/SEL (F) & $2.31 \pm 0.15 \mathrm{a}$ & $4.60 \pm 0.84$ & $33.21 \pm 4.45$ & $0.16 \pm 0.014 \mathrm{ab}$ \\
\hline
\end{tabular}

Values represent mean \pm SEM of six replicates, ${ }^{\mathrm{a}} \mathrm{p}<0.05$ versus untreated unparasitized, ${ }^{\mathrm{b}} \mathrm{p}<0.05$ versus untreated parasitized. GSH: Reduced glutathione,

SOD: Superoxide dismutase, CAT: Catalase, MDA: Mlondialdehyde, SEM: Standard error of mean, ART: Artesunate, AMO: Amodiaquine 


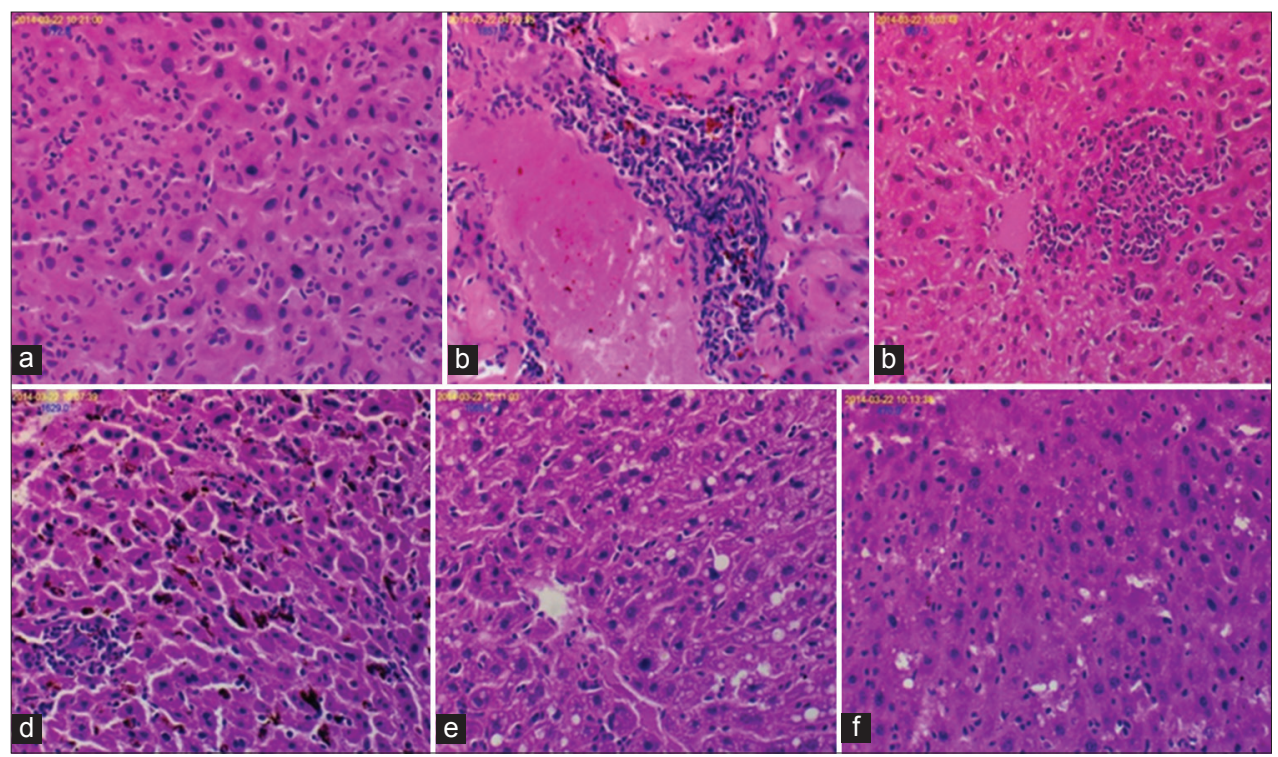

Fig. 1: Photomicrograph of liver of mice: (a) Uninfected showing normal liver (H and E, ×160), (b) infected with Plasmodium berghei showing high amounts inflammatory cells (H and $\mathrm{E}, \times 160)$, (c) treated with $2 \mathrm{mg} / \mathrm{kg}$ bw of artesunate (ART) showing no inflammatory cells ( $\mathrm{H}$ and $\mathrm{E}, \times 160)$, (d) treated with $6.12 \mathrm{mg} / \mathrm{kg}$ bw of amodiaquine (AMO) showing few inflammatory cells $(\mathrm{H}$ and $\mathrm{E}, \times 160),(\mathrm{e})$ liver of mice treated with $2: 6.12 \mathrm{mg} / \mathrm{kg}$ bw of ART and AMO showing presence of intracytoplasmic vesicles ( $\mathrm{H}$ and $\mathrm{E}, \times 160)$, and (f) treated with 2:6.12:0.945 mg/kgbw of ART, AMO and selenium showing a normal liver without inflammatory cells (H and E, ×160)

the damage caused by release of free radicals against cell membranes such as hepatocytes and erythrocytes [29]. However, GSH and SOD were significantly decreased $(\mathrm{p}<0.05)$ in ACT treated group as compared with the positive control. This correlates with the findings of other researchers [30,31]. Reduced GSH level signifies the rate of cellular redox and non-enzymatic antioxidant state of cells in higher animals [32]. The observed reduction in GSH level suggests its increased utilization in mopping out the reactive oxygen species generated by the antimalarial drugs. The significant $(\mathrm{p}<0.05)$ increase in GSH levels in the selenium-supplemented group signifies the antioxidant potential of the micronutrient in opposing the induction of oxidative stress as a result of ACT administration. This correlates with previous research by Adelekan et al. [33] that certain antioxidant micronutrients such as tocopherol could afford defence against malaria-induced oxidative stress and the use of antimalarial drugs. SOD is an antioxidant enzyme that employs superoxide anion as a substrate converting it to hydrogen peroxide which is subsequently utilized by CAT [34]. The significant reduction $(\mathrm{p}<0.05)$ of the enzyme in the group treated with ART and $\mathrm{AMO}$ could be as a result of SOD mobilization to counteract the oxidative stress produced by malaria and the use of ACT. This is because ACT, an antimalarial containing endoperoxide, tends to generate free radicals to combat malaria parasite, thus reducing the antioxidant enzymes [5]. Koracevic et al. [35] reported that the malaria parasite could also degrade these antioxidant enzymes to produce its own protein hence contributing to its depletion in the system. The observed elevation in SOD levels in the group supplemented with selenium further signifies the attempt of the micronutrient to obstruct the induced oxidative stress by ART and AMO administration.

The histopathological analysis of the liver showed the presence of inflammatory cells in the parasitized/untreated group as well as in the group treated with AMO only and the ACT administered group. The presence of these inflammatory cells could be a marker for the degenerative process of the organ as a result of parasite infection. This is also evidenced in the significant increase $(\mathrm{p}<0.05)$ in protein concentration in the group treated with ACT when compared to the control. The absence of inflammatory cells in the group coadministered ART, AMO, and selenium suggest the ability of antimalarial drug supplementation with selenium to restore the normal morphology of the liver.

\section{CONCLUSION}

This study revealed that the combination of ART-AMO therapy with selenium increases the efficacy and reduces potential toxicity of combined antimalarial drugs.

\section{ACKNOWLEDGMENTS}

The authors are grateful to the University through the Covenant University Centre for Research, Innovation and Discovery for the publication support received. We also appreciate the kind support of all laboratory personnel of the Biochemistry Department, Covenant University.

\section{REFERENCES}

1. Hay SI, Guerra CA, Tatem AJ, Noor AM, Snow RW. The global distribution and population at risk of malaria: Past, present and future. Lancet Infect Dis 2004:4:327-36.

2. World Health Organization (WHO). World Malaria Report. Geneva, Switzerland: World Health Organization Press; 2017.

3. World Health Organization (WHO). World Malaria Report. Geneva, Switzerland: World Health Organization Press; 2016.

4. Perkins SL, Schall JA. Molecular phylogeny of malarial parasites recovered from cytochrome B gene sequences. J Parasitol 2002;88:972-8.

5. Ittarat W, Sreepian A, Srisarin A, Pathepchotivong K. Effect of dihydroartemisinin on the antioxidant capacity of $P$. falciparuminfected erythrocytes. Southeast. Asian J Trop Med Public Health 2003;34:744-50

6. Nosten F, White NJ. Artemisinin-based combination treatment of falciparum Malaria. Am J Trop Med Hyg 2007;77:181-92.

7. Olliaro PL, Taylor WR. Developing artemisinin-based drug combinations for the treatment of drug-resistant falciparum Malaria'. A review. J Postgrad Med 2004;50:40-4.

8. Brasseur P, Agnamey P, Gaye O, Vaillant M, Taylor WR, Olliaro PL. Efficacy and safety of artesunate plus amodiaquine in routine use for the treatment of uncomplicated malaria in Casamance, Southern Senegal. Malar J 2007;6:150

9. Martensson A, Stromberg J, Sisowath C, Msellem MI, Gil JP, Montgomery SM, et al. Efficacy of artesunate plus amodiaquine versus that of artemether-lumefantrine for the treatment of uncomplicated childhood Plasmodium falciparum Malaria in Zanzibar, Tanzania. Clin Infect Dis 2005;41:1079-86.

10. Durrani N, Leslie T, Rahim S, Graham K, Ahmad F, Rowland M. Efficacy of combination therapy with artesunate plus amodiaquine compared 
to monotherapy with chloroquine, amodiaquine or sulfadoxinepyrimethamine for treatment of uncomplicated Plasmodium falciparum in Afghanistan. Trop Med Int Health 2005;10:521-9.

11. Newland LW. Handbook of Environmental Chemistry. New York: Springer-Verlag; 1982.

12. Stadtman TC. Some selenium-dependent biochemical processes. Adv Enzymol Relat Areas Mol Biol 1979;48:1-28.

13. Brown KM, Arthur JR. Selenium, selenoproteins and human health: A review. Public Health Nutr 2001;4:593-9.

14. Reitman S, Frankel SA. Colorimetric method for the determination of serum oxaloacetic and glutamic pyruvate transaminase. Am J Clin Pathol 1957;28:56-63.

15. Wright PJ, Leathwood PD, Plummer DT. Enzymes in rat urine: Alkaline phosphatase. Enzymologia 1972;42:317-27.

16. Gonall AG, Bardawill CJ, David MM. Determination of total protein. J Biol Chem 1949;177:751-60.

17. Sedlak J, Lindsay RH. Estimation of total protein-bound, and nonprotein sulfhydryl groups in tissue with Elman's reagent. Ann Biochem J 1968;25:1192-5.

18. Buege JA, Aust SD. Microsomal lipid peroxidation. Methods Enzymol 1978;52:302-10.

19. Sun M, Zigma S. An improved spectrophotometric assay of superoxide dismutase based on epinephrine antioxidation. Ann Biochem J 1978;90:81-9.

20. Aksenes A, Njaa L. Determination of catalase activity in fish. Comp Biochem Physiol 1981;69:893-6.

21. Aliyu R, Okoye ZS, Shier WT. The hepatoprotective cytochrome $\mathrm{P}_{450}$ enzyme inhibitor isolated from Nigerian medicinal plant Cochlospermum planchonii is a Zinc Salt. J Ethnopharmacol 1995;48:89-97.

22. Bhattacharyya D, Mukherjee R, Pandit S, Das N, Sur TK. Prevention of carbon tetrachloride induced hepatotoxicity in rats' by hmmoliv (a poly herbal formulation). Indian J Pharmacol 2003;35:183-5.

23. Iyawe HO, Onigbinde AO. Chloroquine and vitamins combination effects on Plasmodium berghei induced oxidative stress. Int J Biochem Res 2012;2:120-5.

24. Erisir M, Beytut E, Aksakal M, Seyran A. Effect of vitamin E and/ or selenium on alkaline phosphatase activity in the liver, kidneys and heart of prednisolone-injected rats. Kafkas Univ Vet Fak Derg 2010;16:21-5.

25. Klein CJ, Moser-Veillon PB, Schweitzer A, Douglass LW, Reynolds HN, Patterson KY, et al. Magnesium, calcium, zinc, and nitrogen loss in trauma patients during continuous renal replacement therapy. J Parenter Enteral Nutr 2002;26:77-92.

26. Abolaji AO, Eteng MU, Omonua O, Adenrele Y. Influence of coadministration of artemether and lumefantrine on selected plasma biochemical and erythrocyte oxidative stress indices in female Wistar Rats. Hum Exp Toxicol 2013;32:206-15.

27. Farombi EO, Syntum YY, Emerole GO. Influence of chloroquine treatment and $P$. falciparum malaria infection on some enzymatic and non-enzymatic antioxidant defines indices in humans. Drug Chem Toxicol 2003;26:59-71.

28. Adebayo AH, Olasehinde GI, Egbeola OA, Yakubu OF, Adeyemi AO, Adekeye BT. Enhanced Antioxidant Capacity Following Selenium Supplemented Antimalarial Therapy in Plasmodium berghei Infected Mice. AIP Conference Proceedings; 1954. 0300192018.

29. Pabón A, Carmona J, Burgos LC, Blair S. Oxidative stress in patients with non-complicated malaria. Clin Biochem 2003;36: 71-78.

30. Obianime AW, Aprioku JS. Comparative study of artesunate, ACTs and their combinants on the biochemical parameters of male Guinea pigs. Afr J Biotechnol 2009;8:5059-65.

31. Bhattacharya B, Chatterjee TK, Ghosh JK. Effects of chloroquine on lysosomal enzymes, NADPH-induced lipid peroxidation and antioxidant enzymes of rat retina. Biochem Pharmacol 1983; 32:2965-68.

32. Chance B, Sies H, Boveris A. Hydroperoxide metabolism in mammalian organs. Physiol Rev 1979;59:527-5.

33. Adelekan DA, Adeodu OO, Thurnham A. Comparative effect of malaria and malnutrition on plasma antioxidant vitamins in children. Ann Trop Pediatr 1997; 17:223-27.

34. Carrillo M, Kanai S, Nokubo M, Ivy GO, Sato Y, Kitani K. (-) deprenylincreases activites of superoxide dismutase and catalase in stritum but not in hippocampus: The sex and age related differences in the optimal dose in the rats. Exp Neurol 1992;166:286-95.

35. Koracevic D, Koracenc GD, Djevic V. Method for the measurement of antioxidant activity in human fluids. J Clin Pathol 2001;54:356-61. 